\title{
The Modern State in Western \\ Europe: Three Narratives of its \\ Formation
}

O Estado Moderno na Europa

Ocidental: Três Narrativas da sua

Formação

Ramon Blanco

\begin{abstract}
This paper deals with a still very pressing topic, and lively debate, within Political Science and International Relations - the formation of modern states. It delineates the main narratives that seek to explain the formation of the modern state in Western Europe, namely: an economic, a managerial, and a military narrative. Rather than seeking to observe which narrative has more explanatory power over the other, the paper understands each narrative, as well as the authors within them, as an important part of a theoretical mosaic that seeks to understand and explain a dubious, non-linear, diverse and full of setbacks and false starts process that is the formation of the modern state. Therefore, the paper delineates each one of the aforementioned narratives while shedding light on their fundamental arguments, authors and rationale. Finally, the paper provides a middle ground framework in regards to the state formation in Western Europe where the distinct narratives can meet and provide a more comprehensive understanding of the process in which the modern state was formed.
\end{abstract}

\section{Keywords}

State Formation; Modern State; Western Europe.

\section{Resumo}

Este artigo examina um tema central, e um acirrado debate, dentro do campo da Ciência Política e das Relações Internacionais - a formação de estados modernos. $\mathrm{O}$ artigo delineia as principais narrativas que buscam explicar a formação do estado moderno na Europa Ocidental, nomeadamente: as narrativas econômica, gerencial e militar. Ao invés de buscar observar qual narrativa possui um maior poder explicativo relativamente às outras, entende-se que cada narrativa, bem como os autores dentro das mesmas, como uma parte importante de um mosaico teórico que busca entender e explicar o processo dúbio, não-linear e diverso que é a formação do estado moderno. Desse modo, este artigo delineia cada uma das narrativas acima mencionadas destacando seus argumentos, autores e raciocínios fundamentais. Finalmente, o artigo apresenta uma moldura teórica intermediária relativamente ao processo de formação do estado na Europa Ocidental, onde as diferentes narrativas podem encontrar-se de modo a proverem um entendimento mais alargado a respeito do processo pelo qual o estado moderno formou-se.

\section{Keywords}

Formação do Estado; Estado Moderno; Europa Ocidental. 


\section{Introduction}

This paper deals with a still very pressing topic, and lively debate, within Political Science and International Relations - the formation of modern states. It presents, delineates, and most importantly, agglutinates the main narratives that seek to explain the formation of the modern state in Western Europe. Since fundamental practices and processes of current international scenario, namely state-building and peacebuilding efforts in post-conflict scenarios ${ }^{1}$, develop within the framework of, and seek to replicate, the outcomes of this process; it is of utmost importance to have a refined observation of the main narratives that seek to account such process.

In an enterprise such as this, the concept of 'state' certainly cannot be downplayed. Undoubtedly, the concept of 'state' is central to most political analysis and, perhaps because of it, it is a concept widely deployed, very difficult to define, and heavily contested (HAY and LISTER, 2006). Due to the scope, objective and limit of this paper, herein it will not be developed a major understanding of the concept and the debates surrounding it $^{2}$. Herein, it suffices to understand 'state' as a political entity which, internally, has the monopoly of the legitimate law-making, and "its administrative staff successfully upholds the claim to the monopoly of the legitimate use of physical force in the enforcement of its order" (WEBER, [1922] 1978, p. 54). Additionally, it must possess key attributes formulated and agreed in the Montevideo Convention on Rights and Duties of States, which remains "the most widely accepted formulation of the principal criteria of statehood in international law" (CAPLAN, 2005, p. 52). These key attributes are: a permanent population, a defined territory, government, and the capacity to enter into relations with the other states (LEAGUE OF NATIONS, 1936).

Nowadays, to conceive a political entity named 'state' taking part in the ordinary daily life is definitely not something extraordinary for many, if not most, of the people of the world. Nevertheless, this was not always the case. Indeed, as John Hall and John Ikenberry (1989) note it: "most of human history has not been graced by the presence of states" (HALL and IKENBERRY, 1989, p. 16). Though the term 'state'

Has been used retrospectively to refer to mechanisms and processes of political governance arising in Mesopotamia as early as $3000 \mathrm{BC}$, it is only since the seventeenth century that human history has been graced by the concept of the state (HALL and IKENBERRY, 1989, p. 4-5).

According to Colin Hay and Michael Lister (2006), most conventional accounts place the origins of the state "in the transition from the nomadic

\footnotetext{
${ }^{1}$ For more in this regards, see for instance (PARIS and SISK, 2009; RICHMOND and FRANKS, 2009; RICHMOND, 2010).

${ }^{2}$ For this, see for example (VINCENT, 1992; HAY, LISTER and MARSH, 2006).
} 
subsistence of hunter-gatherer to more agrarian societies characterized, increasingly, by organized agriculture" (HAY and LISTER, 2006, p. 5). Furthermore, the authors delineate three key aspects to the beginning of the development of the state as a political entity. Firstly, they argue that only due to the relative geographical immobility, consequence of the agricultural production, that it was possible to build institutions/infrastructure that enabled the governing and the projection of power. Secondly, they highlight religion. This factor was important to the consolidation of state power in the sense that it gave legitimacy to the organized and centralized use of coercive power, often through the appeal of divine authority, enhancing the institutional capacity to govern and to regulate. Thirdly, the ability to mobilize militarily was a high competitive advantage in relation to pre-state-like societies. Rapidly, conquest was a pivotal mechanism through which this institutional form of political organization was diffused (HAY and LISTER, 2006, p. 5). This consequently sparked a snow-ball effect either because conquered would have to adopt the political organization of the conqueror, or because other political organizations should reorganize themselves in order to check the political organization named 'state'.

Nevertheless, as Hay and Lister (2006) correctly remember, "[i]f the origins of the state itself lie in the Mesopotamia, then it is to Western Europe that we must turn if we are to establish the origins of the modern state" (HAY and LISTER, 2006, p. 5). It is somewhat known Max Weber's statement that "[t]he state in the sense of the rational state has existed only in the Western world" (WEBER, [1923] 1961, p. 249). So, apart to the fact that the first state formation processes, in its wildest sense, can be traced far back more than four thousand years ago in ancient Near East and also China, it is the state formation processes in Western Europe that brings the modern understanding of state with a core bureaucratic infrastructure as its backbone (ERTMAN, 2005, p. 367). Hence, "[ $t]$ he state is not universal. It emerged in its modern form between the twelfth and eighteenth centuries in Western Europe" (POGGI, 2004, p. 95). As such, one can reasonably say that, for the political sociological literature, state formation "is usually understood to mean the process by which states are created and then establish and consolidate their monopoly of legitimate violence over a given territory by constructing a durable administrative, financial, judicial, and military apparatus" (ERTMAN, 2005, p. 367). Now, the question lies on how to make sense of this state formation process and its consolidation, and herein lays the fundamental purpose of this paper.

Analyzing key contributions to the state formation literature, Thomas Ertman (2005) argues that three major thinkers inspire whole generations of authors dedicated to this theme. They are: Karl Marx, Max Weber and Otto Hintze. Ertman goes further calling Weber and Hintze the "founding fathers" of state formation theory (ERTMAN, 2005, p. 327). It is clearly feasible to understand each one of these major authors as having a clear influence on each of 
the main accounts on state formation herein delineated. Following Gianfranco Poggi (2004), they can be perfectly labeled, respectively, as: an economic, a managerial, and a military narrative.

The point of the paper is certainly not to seek to investigate which narrative has more weight, or explanation power, than the others. Moreover, the purpose is not also to delineate all possible narratives that seek to explain the state formation process, which could even be counterproductive. The main point here is to delineate the fundamental ones, understanding each narrative, as well as the authors within them, as an important part of a theoretical mosaic that seeks to understand and explain a dubious, non-linear, diverse and full of setbacks and false starts process that is the formation of the modern state. In this sense, this paper is divided in four parts. In each of the three initial parts, it will be presented the three possible narratives for the state formation in Western Europe, namely the economic, managerial and military narratives, while shedding light to the main actors, processes and practices of each one of them. These narratives, rather than isolated approaches, they should be viewed as reciprocally influential and interdependent narratives which, collectively, make a refined account of the state formation process in Western Europe. Finally, the paper presents an understanding about the state formation that can be fairly understood as a middle ground where different explanatory narratives in regards to the process can meet in order to account the state formation process in Western Europe.

\section{The Economic Narrative}

Following Marx, the economic narrative of state formation emphasizes the role played by the class struggle in the process of the formation and consolidation of the states (GOETZE and GUZINA, 2010). It focuses mainly at: where the production and distribution of wealth happens; how it is done; the political phenomena surrounding it; and the conflicts resulting from the formation and development of the state. Hence, it is concerned with the building asymmetry of wealth, and consequently, with the asymmetric allocation of the capacity to exercise coercion. As such, the state is seen "as an outcome of class struggle between producers and exploiters in a capitalist mode of production" (POGGI, 2004, p. 102 and 95).

According to Marx, exploitation, in a capitalist mode of production, does not need the use of force or direct violence. It comes in contractual relations between formally free individuals, once those who are exploited become greatly dispossessed of autonomous control over the means of production. This kind of economic organization requires certain rearrangements of political relations and juridical aspects to work properly (POGGI, 2004). They are: (1) "orderly, purposefully organized cooperation within units and secure exchange between units"; (2) "widening territorial reach of power centers"; (3) "two fundamental developments in the field of private law: the return to the absolute Roman 
conception of property (dominium) and the establishment of contract as the key device for the creation and transmission of rights"; (4) "the contractualization of employer/employee relations allow[ing] capitalists to dismiss any responsibility for the workers' livelihood, to treat labor (power) as commodity"; and (5) "the emergence of a new kind of collective actor - class" (POGGI, 2004, p. 103). Hence, on the one hand, the private property allows those who own it a privileged position regarding the deployment of coercive powers, vested in the police and the judiciary. On the other hand, these rearrangements are essential requisites of the formation and advancement of the capitalist mode of production (Idem). Therefore, for this narrative there is a mutual reinforcement between the two dynamics.

Barrington Moore (1966), in his Social Origins of Dictatorship and Democracy, seeks "to explain the varied political roles played by the landed upper classes and the peasantry in the transformation from agrarian societies [...] to modern industrial ones" (MOORE, 1966, p. 8). It attempts to clarify a range "of historical conditions under which either or both of these rural groups have become important forces behind the emergence of Western parliamentary versions of democracy, and dictatorships of the right and the left, that is, fascist and communist regimes" (MOORE, 1966, p. 8). Moore looks to the internal class structure of states at the beginning of economic modernization correlating critical events, viewed as class struggles, to different political outcomes. As such, he correlates "bourgeois revolution" with Western parliamentary democracies; "revolution form above" with fascist dictatorship; and "peasant revolution" with Communist dictatorship" (SKOCPOL, 1973, p. 4-5). Hence, he delineates "three routes to the modern world" namely: democracy, fascism and communism.

His focus on class structures, its strategies and alliances on the process of state formation is very elucidative regarding the political development of the states. Ertman (2005) argues that although the European state formation was not the very core of the book, these elements are very helpful to understand, for example, the cross-class alliances between: (1) commercially oriented noble landlords and urban bourgeoisie, which took the royal absolutism from power in England; (2) bourgeois excluded from offices, disadvantaged workers and peasant which led to the French Revolution; and (3) between Prussian/German royal bureaucracy and the militarized aristocracy which maintaining a labor repressive agriculture made possible a revolution from above, which led to the fascism on the long run. Simultaneously, Ertman pinpoints the role of demands for taxes in the nurturing of these alliances (ERTMAN, 2005). Ertman (2005) also remembers Skocpol's critique who argues that is necessary to overcome the exclusive intrasocietal focus of the analysis incorporating a world-historic intersocietal perspective (SKOCPOL, 1973) to address the question of state formation.

This was precisely what Immanuel Wallerstein (1974) did in his The Modern World-System observing the role played by states in the emergence and 
reproduction of the, in Wallerstein's words, 'European world economy' (ERTMAN, 2005, p. 373). To Wallerstein (1974), it is evident that the rise of the absolute monarchy in Western Europe is timely coordinated with the emergence of a European world-economy. Furthermore, he argues that "the development of strong states in the core areas of the European world was an essential component of the development of modern capitalism" (WALLERSTEIN, 1974). He perceived a process of an increasing state power throughout the modern era, observing that the capitalist world-economy not only facilitated, but also required this process of increased centralization and internal control. This occurred through four major mechanisms: bureaucratization, monopolization of force, creation of legitimacy, and homogenization of the subject population (WALLERSTEIN, 1974).

The bureaucratization is an important mechanism because it changes fundamentally the political arena in four aspects. First, it enhances the position of the king who now has a new group of permanent and dependent officials at his disposal. Second, the economic policy decisions could not easily bypass the state structure. Third, an efficient bureaucracy would be able to extract from the population and creditors (selling offices, taxing and borrowing more) a financial surplus greater than its maintenance costs. Forth, this increase in revenue allowed the states to enhance its capacity of coercive power and also to create standing armies (WALLERSTEIN, 1974). This connects to the second mechanism, monopolization of force. It was only due to this revenue that the state could pay mercenaries, whose recruitment "was geographically and socially skewed, part and parcel of the new European division of labor". Hence, many of the mercenaries came from the "less-developed" parts of Western Europe (WALLERSTEIN, 1974, p. 139). These not only strengthened the monarch, but also employed the poor, generated revenues for entrepreneurs involved in parallel activities linked to the army, such as its recruitment or its feeding, and, mainly, provided the possibility of internal order (WALLERSTEIN, 1974).

Regarding the creation of legitimacy, Wallerstein (1974) argues that this was not directed to the base of social pyramid but to the top. To him, political stability rested in the ability of the small groups of state managers to convince other political actors, such as a larger group of state staff and regional leaders, "both that the regime was formed and functions on the basis of whatever consensual values these cadres can be made to believe exist and that it is in the interest of these cadres that this regime continue to function without major disturbance" (WALLERSTEIN, 1974, p. 144). To Wallerstein this was achieved through the propagation of the divine right of the kings (WALLERSTEIN, 1974). Finally, regarding the last mechanism, Wallerstein clearly correlates the degree to which the population could be transformed into a culturally homogeneous group and the indication of success of the process of centralizing power. Again, he does not see it as a mechanism mainly targeting the masses, rather "the king, his 
bureaucracy and courtiers, the rural landowners (large and small), the merchants" (WALLERSTEIN, 1974, p. 147). In this sense, Wallerstein observes that "[i]n the sixteenth century, while core states are moving toward greater 'ethnic' homogeneity among these strata, peripheral areas are moving precisely in the opposite direction" (WALLERSTEIN, 1974, p. 147). This was achieved through the expulsion and political weakening of minorities, and also the elimination of religious pluralism.

Clearly influenced by Marx, but also by Weber and Hintze (GOETZE and GUZINA, 2010), Perry Anderson also advances his understanding of the state formation process in Europe. In a directly articulated pair of books (ANDERSON, 1974a), that ultimately develops a single argument (ANDERSON, 1974b), Anderson explores the diverse political outcomes of state development in Europe. He observes three different political outcomes: (1) a moderate absolutism in Western and Southern Europe (France and Spain); (2) a hard one in the East (Brandenburg-Prussia, Austria, Russia); and (3) few cases where it was removed by a bourgeois revolution (England and the Dutch Republic) (ERTMAN, 2005). This differentiation was a result of the uneven development of Europe; the hard economic and social crisis of the fourteenth century divided Europe. Anderson observes that the crisis affected different social classes in diverse forms in distinct states leading to disparate political outcomes. In the West, noble landlords were weakened while royal authority and the towns were strengthened. The exceptions were England and Holland where the bourgeoisie was strong enough to check the absolutist project. In the East, the towns and peasantry were weakened while the nobility was clearly strengthened (ERTMAN, 2005). Hence, Anderson exposes how the uneven development among European states led to different political outcomes. Apart from this, he also places greater weight to a variable, which will be developed later in this paper, than other's influenced by Marx - war and war's preparation - what evidences Hintze's influence on him (ERTMAN, 2005).

Still in the economic narrative but with a different tone, more influenced by the rational choice approach (ERTMAN, 2005), Douglass North and Robert Thomas (1973) also seek to explain the rise of Western Europe. Their argument is that the West rose due to the development of efficient economic organizations in Western Europe. This entails the "establishment of institutional arrangements and property rights that create an incentive to channel individual economic effort into activities that bring the private rate of return close to the social rate of return" (NORTH and THOMAS, 1973, p. 1). In this way, the individuals would be incentivized to perform activities that would bring better social returns. If property rights are ill-defined, the costs of an individual to perform an activity will be greater than its benefits and therefore such activity will not be performed, even though it is socially beneficial. Hence, for them, economic growth will take place if property rights are arranged in such a way that it lowers the individual costs 
making it worthwhile to perform socially productive activities. (NORTH and THOMAS, 1973).

\section{The Managerial Narrative}

In regards to the managerial narrative, it is clear that Weber has a pivotal influence. Although Poggi (2004, p. 95) places Weber, with its emphasis on the state's monopoly of legitimate violence, as majorly influencing a military narrative of state formation, perhaps it makes more sense to place him as influencing the managerial narrative due to his mastery of one key pillars of modern states - the modern bureaucracy ${ }^{3}$. As Weber put it, "[p]atrimonial conditions have had an extraordinary impact as the basis of political structures" (WEBER, [1922] 1978, p. 1013). Hence, for this narrative, according to Ertman (2005) the state formation process "can be seen above all as a struggle between patrimonial rulers and their staffs over control of the "means of administration"" (WEBER, [1922] 1978, p. 369). This is so because, as Weber clarifies it, "[t]he bureaucratic structure goes hand in hand with the concentration of the material means of management in the hands of the master" (WEBER, [1922] 1978, p. 980).

Thomas Ertman (2005) proceeds observing that it was only at the eve of the French Revolution that the rulers in the West started to transform its patrimonial administration into modern bureaucracies. This happened trough: (1) the appropriation of offices by the ruler; (2) their filling with a new corps of university-educated people without any right to the office; and (3) their organization in a functional manner (ERTMAN, 2005). He sees that this transformation, for Weber, was "promoted by [the] needs arising from the creation of standing armies, determined by power politics, and from the related development of public finances" (WEBER, [1922] 1978, p. 972). This point, according to Ertman (2005), approximates Weber to an argument developed by the military narrative (which is highly influenced by Hintze) that sees in the geopolitical competition and threat of war across Europe the basic explanation for its state formation process.

Analyzing also a managerial narrative, Poggi (2004) focuses mainly on two works: Joseph Strayer's (1970) On the Medieval Origins of the Modern States and Harold Berman's (1983) Law and Revolution. Strayer (1970) observed a set of processes that developed in the period from 1100 to 1600 , among them the emergence of political entities that endured in time and had a fixed space. $\mathrm{He}$ (Idem) observed "the development of permanent, impersonal institutions, agreement on the need for an authority which can give final judgments, and acceptance of the idea that this authority should receive the basic loyalty of its subjects". Hence, he focuses on the development of practices and processes concerned with the effective modes of management and political administration of large territories advanced on behalf of rulers by bodies of professional

\footnotetext{
${ }^{3}$ See for example WEBER, (1978 [1922]).
} 
administrators (POGGI, 2004). Strayer (1970) was thus concerned with "the evolving practices relating to the recruitment, training, and employment of those administrators, and with the distinctive practices which they develop [...] and which later become to a certain extent traditional" (STRAYER, 1970). Finally, Strayer (1970) saw the development of the modern state as an ongoing dual process: (1) the development of many and more effective forms of collecting resources; and (2) the provision of services to the public.

Reflecting on Berman's contribution to the state formation debate, Poggi highlights Berman's attention to the role played by the ecclesiastics when he says that "the first state in the West was that which was established in the church by the papacy in the late eleventh and twelfth century" (BERMAN, 1983 apud POGGI, 2004, p.98). To Poggi (2004) this is because the Gregorian reformation expressed and sustained a legal discourse used to "institute, activate, and coordinate ecclesiastical organs - and such discourse was later much used, in properly political bodies, to orient and control binding decisions, including those involving the threat of or the recourse to violence" (POGGI, 2004, p. 98).

Nevertheless, the major contribution of Berman is his argument regarding the key role played by law in the state formation process (POGGI, 2004). The law was important because of two reasons. Firstly, it allowed two dynamics: (1) it reduced eventualities in the conduct of public organisms and in the determination of the population's obligations in the sense that they were all tied to an expressed body of commands valid for everyone; and (2) each law, following certain lawful rules, could be suppressed or changed by another law. In this way, the administrative and juridical organisms could be programmed to operate in certain ways and this act of programming was variable. This facilitated, for example, the extension of the law to territories recently incorporated. Secondly, law was pivotal because it is a sophisticated, very intellectual product which not only could be developed and systematized, but also taught. This fact assisted the rulers and their top administrators to select and to train a very specialized personnel which through the beginning of the modern state formation would replace the feudal and clerical people in the political administration of the state (POGGI, 2004).

\section{The Military Narrative}

The military narrative is essentially concerned about the role of violence in the European state formation processes. It sees this process as the organization, and consequently institutionalization, of internal and external use of violence. The former relates to the suppression of threats to the internal public order through the police and law enforcement. The latter relates to the influence of war, and the preparation to it, to the process of state formation. Clearly, the latter is much more elaborated than the former by the state formation literature. From this narrative, the modern state was from the beginning shaped by war making and by the concern of establishing, maintaining and reinforcing a military capacity. 
Furthermore, it was also very much influenced by the great revenues of war (POGGI, 2004), either stimulating the internal economy, or by the simple assimilation of fortunes.

It can be perceived a major influence of Otto Hintze on the military narrative. To him, "all state constitution is originally war constitution, military constitution" (HINTZE, 1970 apud POGGI, 2004, p. 99). Observing the state formation processes in Europe, Hintze divided them in two categories: (1) the absolutist government with a bureaucratic administration on the continent; and (2) the parliamentary government with a non-bureaucratic administration carried out by nobles in England. Hintze argued that this difference was due to the war, or its threat, emanated from the neighboring forces. Hence, the geopolitical pressure routinely experienced by those in the continent, and less by England, was crucial to the state formation processes. This is because the more exposed to this pressure the rulers were, more they concentrated power in their hands and built professional bureaucracies to administer the standing armies and the whole infrastructure surrounding them such as equipment, payment and provisions (ERTMAN, 2005).

A great contribution to this perspective, and the military narrative, is the book The Formation of National States in Western Europe edited by Charles Tilly (1975a). Tilly problematizes, general aspects but, in the very foreword of the book, Lucian Pye asserts that "[p]ossibly most striking and disturbing is the finding of the authors of this volume that wars and the threats of war played such a critical part in building the strong states of Europe" (TILLY, 1975a, p. XX). Yet, perhaps the greater contribution of Tilly was how he framed the question of state formation and the way he searched for the answer (ERTMAN, 2005). Instead of starting asking what happened, Tilly asked what could have happened in order to investigate the increasing dominance of state in Western Europe (TILLY, 1975b). In order to investigate the state formation process, Tilly adopted a prospective attitude rather than a retrospective one. To him, to compare the Western European countries, like England, France, or Spain, for example, was to study the political organization victor of a hard competition among other kinds of political organizations; it was to frame the inquiry on a kind of outcome that in fact was quite rare (TILLY, 1975b).

For Tilly (1975b), in the thirteenth century, five possible political outcomes were possible: (1) the national state; (2) a political federation or empire with a single center; (3) a theocratic federation structured by the Church; (4) an intensive trading network; and (5) the persistence of the feudal structure present at the time (Ibidem: 26). The state differed from them in some significant forms: the control of a defined and continuous territory; its centralization; its differentiation from other organizations; and the reinforcement of its claims through the acquisition of the monopoly over the concentrated means of physical force within its territory (TILLY, 1975b). 
It is seen though that "[m] ost of the European efforts to build states failed" (TILLY, 1975b, p. 38). Tilly delineates some aspects that influenced the state formation: (1) the availability of extractable resources; (2) a relatively protected position; (3) a continuous supply of political entrepreneurs; (4) success in war; (5) homogeneity/homogenization of the subject population; and (6) a strong coalition of the central power with key segments of the landed elite (TILLY, 1975b). The element that connected and aggregated all these aspects was war and the preparation to it. For him, clearly, the preparation for war was the key state formation activity (TILLY, 1975b). The process of constructing an effective military machine produced arrangements, processes and institutions that remained over time and could be used for other state purposes. This process "tended, indeed, to promote territorial consolidation, centralization, differentiation, of the instruments of government and monopolization of the means of coercion, all the fundamental state-making processes" (TILLY, 1975b, p. 42). This is from where comes Tilly's well-known quotation that "[w]ar made the state and the state made the war" ( TILLY, 1975b, p. 42).

Preparing to, or actually making, war is a very expensive enterprise. Therefore, it is not unusual that the military narrative pays a good attention to resources and its extraction as an important element to the state formation in Western Europe. Still acknowledging the key role of war and its preparation in state formation, the variations in the resource extraction also explain the differentiations within the state formation processes. Observing this element, Tilly refines Hintze's geopolitical argument. Tilly (1985) argued that the principal variations in European state formations resulted from: (1) the variations in the difficult of collecting taxes; (2) the expense of maintaining a certain kind of army; and (3) the amount of war needed to hold enemies.

Later in his work, Tilly (1990) observes the interplay between the concentration of capital and coercion to account for the variations in the state formation processes, delineating three paths. First, the coercion-intensive path, where "rulers squeezed the means of war from their own populations and others they conquered, building massive structures of extraction in the process". Second, the capital-intensive path, where the "rulers relied on compacts with capitalists whose interests they served with care - to rent or purchase military force, and thereby warred without building vast permanent state structures". Finally, an intermediate path was the capitalized coercion mode, where the "rulers did some of each, but spent more of their effort than did their capital-intensive neighbors on incorporating capitalists and sources of capital directly into the structures of their states" (TILLY, 1990, p. 30). This latter path, according to Tilly, was the most "effective in war, and therefore provided a compelling model for states that had originated in other combinations of coercion and capital" (TILLY, 1990, p. 31).

Still in this line of thought, Brian Downing (1992) conjugates the geopolitical view with the internal mobilization of resources to develop his 
argument. Downing saw in the medieval Western Europe a whole set of institutions that counterbalanced the royal power - "the rule of law, a developed conception of rights, autonomous cities, decentralized military organization and above all representative institutions - institutional arrangements that Downing collectively terms medieval constitutionalism" (ERTMAN, 2005, p. 378). Ertman (2005) sees that while accounting the impact of changes in military technology, and its consequence in size and costs, in the state formation process, Downing's argument can be summarized as follows: where the war was so heavy and protracted that required a great domestic resource mobilization, that constitutionalism was broke and saw the emergence of a military-bureaucratic form of government. Where the war was light or its requirements could be developed without a great internal mobilization effort the constitutional kind of government prevailed. Finally, where warfare was protracted, military modernization and political centralization were prevented, and foreign resources were absent, the lost of sovereignty to stronger states was the fate (DOWNING, 1992).

\section{A Possible Middle Ground on State Formation}

Observing the aforementioned narratives, it is clear that Francis Fukuyama (2011), in his The Origins of Political Order, perhaps best sums up the state formation discussion and offers what could be easily understood as a middle ground where different narratives on state formation can meet, while delineating a framework for the process. For him, war, and the threat of it, was a key element during the state formation process. Areas where this element was absent developed modern states relatively later than where the military competition was present. In order to engage in war, the state had to mobilize a large, and increasing, amount of resources. On the one hand, this increasing need for resources lead to a higher taxation and to an extension of the state's domain in other to tax more people and resources. On the other hand, the state had to collect better. Consequently, it was developed a process of more centralization, bureaucratization and rationalization (FUKUYAMA, 2011).

The kind of state developed is, to Fukuyama, the result of the interaction among these states and the social groups within the society. The relationship of cooptation and resistance between the centralizing efforts and the social groups is essential to the variation of outcomes. The social groups delineated by Fukuyama (2011) are the upper nobility, the gentry and the Third Estate. The first group he describes as those who had their own land, army and resources. They also governed their own territory. The second group consisted of lesser elites (small landowners, knights, or other individuals), which had social status but did not necessarily have a significant amount of land and resources. The third one was composed by tradesmen, merchants, free serfs and those living in towns and cities. They were the incipient bourgeoisie. The peasantry, which was the vast majority 
of the population, was not a significant political actor for Fukuyama since they rarely mobilized a collective action in order to represent their interests.

Whereas the state sought to expand its domination, the social groups sought to protect and increase their privileges, in absolute and in relation to each other. It is the degree of resistance to the state's centralization efforts, which depended on both internal cohesion of the social groups and their ability to cooperate, that shaped the state formation outcome. In a few words, when the social groups were weak, badly organized or the state could co-opt them, absolutist governments emerged. Accountable governments emerged when the state was relatively weak, the social groups were well-organized, and the relationship between them was well-balanced (FUKUYAMA, 2011).

Furthermore, to Fukuyama, a successful state would combine a stable balance of three important political institutions: the state itself, the rule of law, and an accountable government. According to Fukuyama, the state is understood as the centralized source of authority which had the monopoly of the legitimate use violence over a defined territory. Regarding the rule of law, he argues that, often, social rules were formalized as written laws which were used to organize how power was distributed regardless the person exercising power and the time. Those written laws, with time, were gaining supreme authority over the whole society and the rulers who temporally headed the military and the bureaucracy. It was at that point, for him, that institutions superseded individual leaders. Moreover, certain societies also made their states accountable through the formation of parliaments, assemblies and bodies of representation of the population. Hence, one the one hand, the state concentrated the power, made the citizens compliant with the laws, and defended itself and its population from outside threats. On the other hand, the rule of law and accountable government limited state's power, making it operate within certain rules, and ensure that the state would be subordinates to the will of the population (FUKUYAMA, 2011). Hence, one can certainly understand the formation of the modern state in Western Europe as a majorly internally-driven process where the interplay of pivotal social actors would shape the characteristics of the resulting political entity.

\section{Conclusion}

This paper sheds light on the process of the formation of modern states in Western Europe. Throughout the paper, three main explanatory narratives of the process, namely the economic, a managerial, and a military narrative are analyzed. As delineated above, each of these narratives has a major thinker having a decisive influence on the possible explanations for the emergence of the modern state. They are respectively, Karl Marx, Max Weber and Otto Hintze. In regards to the process per se, taking into all account these studies, it is safe to argue that the state formation process was developed, mainly, through internal processes, rather than international ones. Certainly there were international influences to the 
process. War, or the threat of it, for instance, was a key one. It was the threat of war, or the necessity of engaging on it, that created the need for resources. This led not only to a centralization of power and means of violence, but also to a fierce bureaucratization and consequently its rationalization. Therefore, it is quite reasonably to understand the state formation process as being the result of the relationship among different domestic political actors. For instance, whereas the Church was key to the development of a bureaucratic organization, and to the formation of an institutionalized and independent legal order, it was how this centralized bureaucratic organization interacted with key players of the social body that constituted the important element for defining the characteristics of the resulting state. In order to reach such understanding, one should perceive each one of the narratives herein delineated not as the explanatory narrative of the state formation process, but as an important part of a more comprehensive approach to understanding the complexities of the formation of the modern state in Western Europe.

\section{Ramon Blanco é Pesquisador Associado no Centro de Estudos Sociais (CES) da Universidade de Coimbra (UC) e Doutorando em Política Internacional e Resolução de Conflitos da UC. E-mail: blanco.ramon@gmail.com}

\section{References}

ANDERSON, Perry. Lineages of the Absolutist State. London: New Left Books, 1974a. 1974b.

Passages from Antiquity to Feudalism. London: New Left Books,

BERMAN, Harold J. Law and Revolution - The Formation of the Western Legal Tradition. Cambridge: Harvard University Press, 1983.

CAPLAN, Richard. Europe and the Recognition of New States in Yugoslavia. Cambridge: Cambridge University Press, 2005.

DOWNING, Brian. The Military Revolution and Political Change. Origins of Democracy and Autocracy in Early Modern Europe. Princeton: Princeton University Press, 1992.

ERTMAN, Thomas. State Formation and State Building in Europe. In: JANOSKI, Thomas; ALFORD, Robert R.; HICKS, Alexander M.; SCHWARTS, Mildred A. (eds.). The Handbook of Political Sociology - States, Civil Societies, and Globalization. Cambridge: Cambridge University Press, 2005. p. 367-383.

FUKUYAMA, Francis. The Origins of Political Order - From Prehuman Times to the French Revolution. New York: Farrar, Straus and Giroux, 2011. 
GOETZE, Catherine; GUZINA, Dejan, 2010, "Statebuilding and Nationbuilding", International Studies Encyclopedia Online. 2010. Disponível em: <http://www.isacompendium.com/subscriber/ tocnode?id=g9781444336597_ chunk_g978144433659718_ss1-12>. Acesso em: 10 mar. 2013.

HALL, John A.; IKENBERRY, John. The State. Buckingham: Open University Press, 1989.

HAY, Colin; LISTER, Michael. Introduction: Theories of the State. In: HAY, Colin; LISTER, Michael; MARSH, David (eds.). The State - Theories and Issues. London: Palgrave Macmillan, 2006. p. 1-20.

HAY, Colin; LISTER, Michael; MARSH, David (eds.) The State - Theories and Issues. London: Palgrave Macmillaned. 2006.

LEAGUE OF NATIONS. Convention on Rights and Duties of States. League of Nations Treaty Series, v. 165, n. 3802, nov. 1936.

MOORE, Barrington. Social Origins of Ditactorship and Democracy: Lord and Peasant in the Making of the Modern World. Harmondsworth: Penguin University Books, 1966.

NORTH, Douglass; THOMAS, Robert. The Rise of the Western World. Cambridge: Cambridge University Press, 1973.

PARIS, Roland; SISK, Timothy (eds.). The Dilemmas of Statebuilding: Confronting the Contradictions of Postwar Peace Operations. New York: Routledgeed, 2009.

POGGI, Gianfranco. Theories of State Formation. In: NASH, Kate; SCOTT, Alan (eds.). The Blackwell Companion to Political Sociology. Oxford: Blackwell Publishing, 2004. p. 95-106.

RICHMOND, Olivier (ed.) Palgrave Advances in Peacebuilding: Critical Developments and Approaches. London: Palgrave Macmillaned, 2010.

RICHMOND, Olivier; FRANKS, Jason. Liberal Peace Transitions - Between Statebuilding and Peacebuilding. Edinburgh: Edinburgh University Press, 2009.

SKOCPOL, Theda. A Critical Review of Barrington Moore's Social Origins of Dictatorship and Democracy. Politics Society, v. 4, n. 1, p. 1-34, set. 1973.

STRAYER, Joseph. On the Medieval Origins of the Modern States. Princeton: Princeton University Press, 1970.

TILLY, Charles (ed.). The Formation of National States in Western Europe. Princeton: Princeton University Pressed, 1975a.

Reflections on the History of European State-Making. In: TILLY, C. (ed.). The Formation of National States in Western Europe. Princeton: Princeton University Press, 1975b. p. 3-83.

War Making and State Making as Organized Crime. In: EVANS, P.; RUESCHEMEYER, Dietrich; SKOCPOL, Theda (ed.). Bringing the State Back. Cambridge: Cambridge University Press, 1985. p. 169-191. 
Coercion, Capital, and European States, Ad 990-1992. Oxford: Blackwell Publishers, 1990.

VINCENT, Andrew. Conceptions of the State. In: HAWKESWORTH, Mary; KOGAN, Maurice (ed.). Encyclopedia of Government and Politics - Volume I. London: Routledge, 1992. p. 43-55.

WALLERSTEIN, Immanuel. The Modern World-System - Capitalist Agriculture and the Origins of the European World-Economy in the Sixteenth Century. New York: Academic Press Inc, 1974.

WEBER, Max. In: ROTH, Guenther; WITTICH, Claus (ed.). Economy and Society - An Outline of Interpretive Sociology. Berkeley: University of California Press, [1922] 1978. General Economic History. New York: Collier Books, [1923] 1961.

Texto recebido em 23 de outubro de 2013. Aprovado em 20 de novembro de 2013. 